\title{
Model Pembelajaran Pada Masa Covid-19 di Indonesia
}

\author{
${ }^{*}$ Hairiah \\ SDN 007 Sangkulirang Dinas Pendidikan Kutai Timur, Indonesia \\ *latif.hairiah@yahoo.com (Corresponding Author)
}

\begin{tabular}{|c|c|}
\hline (A) Check for updates open 0 access @C) (i) & DOI: https://doi.org/10.53621/jider.v1i1.15 \\
\hline Informasi Artikel & ABSTRAK \\
\hline Riwayat Artikel: & \multirow{10}{*}{$\begin{array}{l}\text { Tujuan penelitian ini untuk mendeskripsikan model pembelajaran pada masa } \\
\text { Covid-19 di Indonesia, karena masa Covid-19 ini pembelajaran menggunakan } \\
\text { online dan pembelajaran jarak jauh yang menuntut penerapan model } \\
\text { pembelajaran yang tepat dan dapat dilaksanakan dengan baik. Metode } \\
\text { dengan kualitatif kajian literatur atau penelitian kepustakaan dengan analsis } \\
\text { isi. Hasil penelitian menemukan adanya pembelajaran online atau daring } \\
\text { pada masa pandemi COVID-19 sangat berpengaruh terhadap minat belajar } \\
\text { peserta didik, peserta didik merasa bosan karena tidak bertemu dengan } \\
\text { teman dan gurunya secara langsung. Pandemi COVID-19 yang telah } \\
\text { mempengaruhi banyak hal termasuk kehidupan pendidikan, orang tua } \\
\text { peserta didik, peserta didik dan proses pembelajaran, sehingga perlunya } \\
\text { seorang guru yang memiliki tanggung jawab untuk benar-benar mendidik } \\
\text { para peserta didik dimana para guru harus menemukan cara yang sesuai } \\
\text { untuk mempromosikan proses pembelajaran dengan model pembelajaran } \\
\text { yang ditemukan dalam penelitian ini adalah model pembelajaran Cooperative } \\
\text { Learning, Model pembelajaran Problem Based Learning (PBL), model } \\
\text { pembelajaran Project Based Learning (PjBL), Model pembelajaran flipped } \\
\text { classroom (FC), Model pembelajaran Lietarasi Digital (LD). }\end{array}$} \\
\hline Diterima: 22 Agustus 2021 & \\
\hline Revisi Akhir: 25 Agustus 2021 & \\
\hline Disetujui: 25 Agustus 2021 & \\
\hline Terbit: 25 Agustus 2021 & \\
\hline Kata Kunci: & \\
\hline Model pembelajaran, & \\
\hline Dampak Covid-19, & \\
\hline Pembelajaran Online. & \\
\hline & \\
\hline
\end{tabular}

\section{PENDAHULUAN}

Indonesia termasuk negara yang mengalami musibah penyebaran virus corona yang menjadi masalah dunia saat ini. Dengan musibah itu pemerintah telah menerapkan kebijakan pembelajaran jarak jauh dan belajar melalui daring atau online untuk meminimalisir dampak covid-19. Covid-19 mengancam kesehatan dan jiwa manusia karena virus yang bisa menyebabkan kematian (Satgas, 2020; Shao \& Wu, 2020), sejak 2019 virus ini ditemukan disalahsatu provinsi di negara china (Huang et al., 2020; Wang et al., 2020) telah menyebar dengan cepat ke seluruh dunia.

Kondisi ini sudah berjalan dua tahun sejak 2019 hingga 2021, pembelajaran pun dijalankan dengan online atau pembelajaran jarak jauh (PJJ) di tengah ancaman dan bencana Covid-19 (Firman \& Rahayu, 2020), pembelajaran harus tetap dijalankan walaupun kondisi tidak memungkinkan tatap muka secara langsung, maka dilaksanakanlah secara virtual (Munawaraoh, 2005). Pembelajaran saat Covid-19 ini bermunculan beragam pendekatan aplikasi online yang digunakan. Ada yang menggunakan LMS sebagai salah satu cara yang cocok pembelajaran jarak jauh (Abazi-Bexheti et al., 2018), menggunakan zoom (Brahma, 2020; Haqien \& Rahman, 2020; Vhalery et al., 2021), ada pula guru dan para pendidikan mengadopsi media sosial dalam pembelajaran jarak jauh, menggunakan Whatsapp dan media sosial lainnya (Daheri et al., 2020; Fauziah et al., 2021; Salehudin, 2020a).

Namun yang menarik selain aktivitas penggunaan aplikasi pembelajaran online, penggunaan media dan multimedia serta pengembangan bahan ajar di masa online ini adalah penggunaan model pembelajaran. Dimana model pembelajaran adalah bagian penting dalam proses pembelajaran yang mengarahkan aktivitas pembelajaran mencapai tujuannya.

Model pembelajaran adalah menciptakan lingkungan-lingkungan untuk memudahkan pembelajaran (Joyce et al., 2015), lebih jauh Bruce Joyce menyebut bahwa model pembelajaran 
adalah cara membangun asuhan dan menstimulasi ekosistem di mana di dalamnya para peserta didik belajar dengan berinteraksi denagn komponen-komponennya.

Model pembelajaran itu membantu peserta didik mempelajari bagaimana untuk belajar dengan gayanya sendiri, setiap model yang terpilih dan digunakan dalam aktivitas pembelajaran membantu peserta didik menyusun strategi belajarnya dan memberikan cara melakukab aktivitas belajarnya. Sehingga munculnya istilah model pembelajaran. Model pembelajaran dapat diklasifikasikan berdasarkan tujuan pembelajarannya. Sebagai salah satu contoh adalah pembelajaran berbasis proyek (Juwanti et al., 2020; Kokotsaki et al., 2016; Salehudin, 2020b), pembelajaran berdasarkan tujuan yaitu pembelajaran langsung, suatu model pembelajaran yang baik untuk membantu peserta didik dalam mempelajari keterampilan dasar atau topik-topik bahasan (Fuadi \& Muchson, 2020).

Dikenal pula model yang banyak digunakan pada pembelajaran dunia saat ini, pembelajaran dengan blended (Artal-Sevil, J. S., Romero-Pascual, E., \& Artacho-Terrer, 2015; Romadhon et al., 2019), kemudian model teknologi dan pembelajaran terbalik yaitu flipped, model ini juga banyak digunakan flipped dengan afikasi diri (Kinteki et al., 2019), flipped dengan teknologi dan menggunakan LMS atau learning managemen system (Elfeky et al., 2020), Pembelajaran model flipped classroom pertama peserta didik mempelajari topik sendiri, biasanya menggunakan pelajaran video yang dibuat oleh guru atau bersama oleh pendidik lain, guru tidak harus menciptakan video pembelajaran sendiri. Kemudian dalam kelas, peserta didik kemudian mencoba untuk menerapkan pengetahuan dengan memecahkan masalah dan melakukan kerja praktek. Pembelajaran model flipped classroom bukan hanya sekedar belajar menggunakan video pembelajaran, namun lebih menekankan tentang memanfaatkan (Gawise et al., 2021).

Selain model pebelajaran tersebut di atas, masih banyak pula model pembelajaran yang banyak digunakan oleh para pendidik pada semua level pendidikan, dari pendidikan anak usia dini hingga pendidikan tinggi. Model pembelajaran selain membantu peserta didik bertanggung jawab untuk pembelajaran dan memisahkannya juga membantu peserta didik meraih pengetahuan, keterampilan dan pemahaman diri yang baru. Untuk menyukseskan pengajaran membantu peserta didik belajar melampaui keberadaan mereka saat ini. Bagi guru mereka menjadi wahana belajar berinteraksi terhadap peserta didik, mangatur kemampuan sosialisasi antara pendidik dengan peserta didik, maupun antar sesama teman. Tidak hanya itu saja, pendidik dapat mengamati secara langsung sikap dan tingkah laku mahasiswa dalam menerima materi.

Mengingat banyaknya literatur yang membahas tentang model pembelajaran di masa pembelajaran abad 21 saat ini, maka menarik untuk diangkat dalam penelitian yang membahas tentang model pembelajaran pada masa Covid-19 di Indonesia, karena masa Covid-19 ini pembelajaran menggunakan online dan pembelajaran jarak jauh yang menuntut penerapan model pembelajaran yang tepat dan dapat dilaksanakan dengan baik.

\section{METODE PENELITIAN}

Penelitian ini dengan pendekatan kualitatif studi literatur atau penelitian kepustakaan (Creswell, 2014), membaca dan mengkaji beberapa artikel internasional dan nasional untuk menjawab tujuan penelitian tersebut. Penelusuran artikel menggunakan Google Sholar, DOAJ. Dalam penelitian deskriptif analitif, penggalian sumber dilakukan dengan mengumpulkan teoriteori dan pembahasan mengenai isu-isu terkait model pembelajaran di masa pandemi Covid-19. Selanjutnya, peneliti akan melihat dari berbagai sudut pandang berkenaan tentang kompetensikompetensi apa yang dibutuhkan guru pada saat ini dengan melihat fenomena atau kenyataan yang ada.

Analisis dilakukan pada berbagai artikel ilmiah terkait model pembelajaran selama masa pandemic COVID-19. Artikel ilmiah diperoleh dari jurnal internasional, nasional dan berbagai sumber lain yang sejenis. Peneliti lalu menganalisis dan mendeskripsikan hasil temuan yang ada berdasarkan hasil kajian dan pengamatan (Sugiono, 2010). 


\section{HASIL DAN PEMBAHASAN}

Dalam proses pembelajaran peran guru harus mampu menguasai berbagai model pembelajaran, didukung dengan penggunaan media pembelajaran dengan menggunakan TIK dimana karena kondisi selalu berubah-rubah terlebih pada saat sekarang ini yang masih diliputi pandemi Covid-19 mengancam kesehatan manusia, sehingga berbagai sektor aktivitas manusia mengalami pembatasan, pengaturan serta perubahan dan dituntut untuk menyesuaikan dengan keadaan tersebut. Termasuk juga dunia pendidikan pada semua level pendidikan yang harus mentransformasikan berbagai model pembelajaran di masa pandemi Covid-19.

Penutupan sekolah menjadi langkah mitigasi paling efektif untuk meminimalisir penyebaran wabah pada anak- anak. Solusi yang diberikan yakni dengan memberlakukan pembelajaran dirumah dengan memanfaatkan berbagai fasilitas penunjang yang mendukung (Herliandry, et al., 2020). Memerlukan adanya inovasi model pembelajaran yang menyesuaikan dengan kondisi Covid-19 tidak hanya melibatkan perangkat dan peningkatan manfaat penggunaan model, tetapi proses pembelajaran dirancang atau direkayasa ulang untuk memberikan manfaat dalam mencapai tujuan belajar peserta didik pada khususnya.

Berbagai aktivitas Guru dan peserta didik, dimana guru dapat mengkomunikasikan tujuan, materi, waktu, kecepatan, dan hasil akhir yang diharapkan dari peserta didik, serta penilaian yang akan diterapkan. Pembelajaran menjadi menarik dimana dengan bantuan guru, peserta didik merencanakan bagaimana mengumpulkan data dan kegiatan belajar lainnya, seperti browsing internet dan perpustakaan serta melakukan investigasi. Implementasi peserta didik melaksanakan rencana yang telah dibuat dengan strategi dan sumber belajar yang berbeda. peserta didik mengeksplorasi cara penyelidikan terhadap masalah/konsep yang akan dipelajari. Investigasi dapat dilakukan dengan berbagai cara, seperti membaca, observasi, wawancara, melakukan eksperimen, browsing melalui internet, dan sebagainya. Dalam model pembelajaran bisa saja menggunakan model yang menekankan adanya penyelidikan dilakukan secara berkelompok sesuai dengan kesepakatan. Selama proses investigasi, peserta didik dapat berkomunikasi dengan guru melalui email, whatsapp atau facebook sebagai aplikasi yang mendukung terlaksananya model pembelajaran.

Model pembelajaran merupakan kerangka konseptual yang menggambarkan prosedur yang sistematis dalam menyelenggarakan pembelajaran pengalaman untuk mencapai tujuan pembelajaran tertentu dan menjadi pedoman bagi guru dalam merencanakan dan melaksanakan kegiatan pembelajaran (Joyce et al., 2015). Model pembelajaran yang mengintegrasikan materi dan pokok bahasan memberikan lebih banyak kesempatan kepada peserta didik untuk belajar lebih banyak dengan menggunakan TIK sebagai sumber informasi, diantaranya mengirim draft tugas atau makalah untuk ditinjau oleh guru dan teman, dan menyebarluaskan karya yang dihasilkan.

\section{Pembelajaran online}

Sistem pembelajaran dilaksanakan melalui perangkat personal computer (PC) atau laptop yang terhubung dengan koneksi jaringan internet. Memungkinkan adanya peran guru dapat memastikan peserta didik mengikuti pembelajaran dalam waktu bersamaan, meskipun di tempat yang berbeda. Selain posisi guru, pemberian tugas dapat terukur sesuai dengan tujuan materi yang disampaikan kepada peserta didik. Bahwa pembelajaran daring pada masa pandemi COVID-19 sangat berpengaruh terhadap minat belajar peserta didik, peserta didik merasa bosan karena tidak bertemu dengan teman dan gurunya secara langsung (Yunitasari \& Hanifah, 2020). Pembelajaran jarak jauh yang dilakukan guru dalam meningkatkan life skill anak usia dini dan memberikan informasi tentang hambatan yang terjadi pada pelaksanaan pembelajaran jarak jauh.

Pembelajaran online dilaksanakan dengan bantuan internet, para guru dapat melakukan pembelajaran bersama di waktu yang sama menggunakan grup di media sosial seperti WhatsApp (WA) (Daheri et al., 2020), telegram, instagram, aplikasi zoom ataupun media lainnya sebagai media pembelajaran (Herliandry, Nurhasanah, Suban, \& Heru, 2020). Manfaat dan hal 
positif dengan adanya pembelajaran online pembelajaran daring dapat dikatakan menjadi satusatunya pilihan pembelajaran yang dapat dilakukan oleh pendidik untuk menigkatkan mutu pembelajaran di Indonesia (Syarifudin, 2020).

Menurut Setyorini (2020), dimana posisi guru harus dapat mengelola kelas di kelas dan kelas online. Disebabkan adanya pandemi COVID-19 yang telah mempengaruhi banyak hal termasuk kehidupan pendidikan, orang tua peserta didik, peserta didik dan proses pembelajaran, sehingga perlunya seorang guru yang memiliki tanggung jawab untuk benarbenar mendidik para peserta didik dimana para guru harus menemukan cara yang sesuai untuk mempromosikan proses pembelajaran secara akademis dan sosial-emosional., juga guru harus dapat mengelola kelas di kelas dan kelas online (Setyorini, 2020). Berjalannya waktu dalam pelaksanaan pembelajaran online banyak terjadi kendala dan hambatan ketika penerapan sistem pembelajaran online ini di antaranya ditemukan tidak meratanya peserta didik dan orang tua yang pandai mengoperasikan aplikasi yang digunakan online, tidak semua orang tua mampu membeli kuota internet, signal internet di rumah bahkan tidak terjangkau dengan baik, kendala yang terbesar dari sektor pendapatan atau penghasilan orangtua yang kondisi ekonominya di bawah rata-rata, ada pula yang tidak memiliki smartphone sebagai sarana belajar secara online (Agustin et al., 2020). Pembelajaran online atau daring menunjukkan bahwa pembelajaran daring pada masa pandemi COVID-19 sangat berpengaruh terhadap minat belajar peserta didik, peserta didik merasa bosan karena tidak bertemu dengan teman dan gurunya secara langsung (Yunitasari \& Hanifah, 2020).

Penelitian Pujiasih (2020) dengan data kuesioner pada 322 peserta didik diperoleh kelebihan dan kekurangan pembelajaran online ini dimana peserta didik yang senang belajar online di rumah $45 \%$ dan peserta didik yang tidak senang $55 \%$. Kelebihan pembelajaran ini peserta didik lebih efektif dalam belajar, tidak lelah, menyenangkan, pengalaman baru dan kelemahannya adalah koneksi internet yang kurang baik, peserta didik kurang paham dengan materi, peserta didik merasa lelah, peserta didik tidak bisa berdiskusi dengan teman. Berdasar dari masalah tersebut maka pembelajaran online yang menarik dan bervariasi akan memberikan manfaat bagi generasi emas dalam belajar (Pujiasih, 2020). Orang tua menjadi seseorang yang sangat penting dalam pelaksanaan pembelajaran daring, karena orang tua secara yang secara langsung terlibat dalam membimbing dan mengawasi peserta didik dalam pembelajaran. Pemberian motivasi menjadi sangat berarti bagi peserta didik, hal tersebut dilakukan agar peserta didik kembali semangat meskipun belajar dari rumah (Putria et al., 2020).

Ditemukan pula hal positif, dalam penelitian yang dilakukan untuk melihat pembelajaran jarak jauh mampu meningkatkan life skills pada anak usia dini. Kerjasama orang tua dengan guru dalam menciptakan anak yang disiplin pada pembelajaran online saat ini (Yatun et al., 2020). Walaupun masih ada terdapat hambatan pada pelaksanaan pembelajaran jarak jauh yaitu ada beberapa anak yang masih belum terbiasa dengan pembiasaan menghafal dan mengerjakan tugas sehingga belum mau melakukannya (Rakhman \& Alam, 2020).

Pembelajaran online memberikan kemudahan dalam memberikan transfer informasi pada berbagai situasi dan kondisi. Ragam manfaat dari kemudahan pembelajaran online didukung berbagai platform mulai dari diskusi hingga tatap muka secara virtual. Namun, hal ini perlu di evaluasi dan disesuaikan dengan kondisi setempat, mengingat kemampuan orang tua memberikan fasilitas pembelajaran online berbeda. Kuncinya adalah memaksimalkan kemampuan peserta didik belajar dalam kondisi pandemic seperti ini (Herliandry, Nurhasanah, Suban, \& Kuswanto, 2020).

\section{Model Pembelajaran}

Pada masa pandemi Covid-19 yang melanda Indonesia, maka penerapan model pembelajaran semakin bervariasi, menuntut adanya wawasan dan pengetahuan guru untuk dapat menerapkan dengan maksimal, diantara model pembelajaran yang ditemukan dalam penelitian ini adalah model pembelajaran Cooperative Learning, Model pembelajaran Problem Based Learning (PBL), model pembelajaran Project Based Learning (PjBL), Model pembelajaran flipped 
classroom (FC), Model pembelajaran Lietarasi Digital (LD). Selanjutnya akan dijabarkan berikut ini:

\section{Model pembelajaran Cooperative Learning tipe take and give}

Diperoleh dari hasil penelitian yang dilakukan mengenai model pembelajaran Cooperative Learning tipe take and give; dalam Septiani (2018) tipe take and give efektif terhadap peningkatan hasil belajar dilihat dari pengaruhnya terhadap hasil belajar tersebut. Selain pengaruhnya terhadap hasil belajar, model pembelajaran tipe take and give tersebut yang juga berpengaruh pada penerapan model pembelajaran tipe take and give terhadap keterampilan sosial peserta didik (Adawiyah, 2017). Salah satu tipe model pembelajaran kooperatif bagi peserta didik yang diminta untuk saling berbagi dengan teman kelompoknya yang berkenaan dengan topik pembahasan yang diberikan guru. Penekanan Model pembelajaran ini melatih peserta didik untuk aktif dan saling berkolaborasi dalam menyampaikan materi yang diterima, untuk kemudian materi tersebut di transfer kepada teman-teman lainnya secara berulang-ulang. Dalam penerapannya, Model Pembelajaran Cooperative Learning Tipe Take and Give dapat dengan menggunakan media berupa kartu materi sebagai alat bantu dalam pembelajaran. Banyak penelitian yang menemukan bahwa peserta didik yang menggunakan media dalam proses belajar seperti alat peraga atau media pembelajaran maka akan menghasilkan nilai lebih adalam proses pembelajarannya.

\section{Model Pembelajaran Problem Based Learning (PBL)}

Dampaknhya dimana penerapan Model Pembelajaran Problem Based Learning (PBL) pada masa pandemi covid 19 dalam meningkatkan aktivitas dan hasil belajar peserta didik pada mata pelajaran produk kreatif dan kewirausahaan. Selanjutnya Fuadi dan Muchson (2020) menemukan dalam penelitiannya adanya implementasi model pembelajaran Problem Based Learning dapat meningkatkan keaktifan belajar peserta didik kelas XI TKJ di SMK Hidayatus Sholihin pada mata pelajaran PKK. Hal ini berdasarkan data pengamatan dari semua indikator yang diamati pada siklus I dengan persentase keaktifan belajar peserta didik sebesar $62,01 \%$ dan meningkat pada siklus II sebesar $76,30 \%$ dan meningkat pada lagi pada siklus III dengan persentase keaktifan belajar peserta didik sebesar 80,19\% (Fuadi \& Muchson, 2020). Dalam penyelesaian tugas yang diberikan oleh guru, masingmasing peserta didik dalam kelompok antusias dalam mengerjakannya. Dengan demikian maka model pembelajaran PBL ini dapat meningkatkan keaktifan belajar peserta didik.

\section{Model pembelajaran Project Based Learning (PjBL)}

Model pembelajaran Project Based Learning (PjBL) dengan bimbingan guru, kemerdekaan peserta didik dalam belajar akan terasa saat menggunakan e-learning dengan tidak meninggalkan peran guru. literasi digital perubahan pengajaran beralih pada kebebasan meramu materi sesuai dengan kebutuhan peserta didik dengan alat bantu atau media komputer, sehingga pengajaran tidak monoton (Pohan \& Suparman, 2020, Safaruddin et al., 2020), sedangkan sintaks PjBL (1). Penentuan Pertanyaan Mendasar (Start with the Essential Question), (2). Mendesain Perencanaan Proyek (Design a Plan for the Project), (3). Menyusun Jadwal (Create a Schedule), (4). Memonitor pebelajar dan kemajuan proyek (Monitor the Students and the Progress of the Project), (5). Menguji Hasil (Assess the Outcome), (6). Mengevaluasi Pengalaman (Evaluate the Experience) dalam pembelajaran akan memberikan pengalaman dan pengetahuan baru bagi pebelajar karena secara tidak langsung belajar menjadi ilmuan, melakukan tindakan secara ilmiah dalam melaksanakan suatu proyek, yang menjadi dalam sebuah rangkaian ilmiah yang terdiri atas merumuskan permasalahan, menentukan prosedur, menentukan cara/langkah-langkah yang dibutuhkan, melakukan penyelidikan, mendesain dan menciptakan produk, mempresentasikan atau komunikasikan produk sebagai hasil dari proses penyelidikan, dan melakukan diskusi hasil (Salehudin, 2020b). PjBL berbantuan e-learning dan self-efficacy secara bersama-sama (simultan) terhadap hasil belajar pemahaman konsep didukung dengan kekuatan model pembelajaran, 
kekuatan e-learning, interaksi kelas dan kolaborasi kelompok, materi dan media serta lingkungan yang menjadikan pengaruh dan signifikan terhadap hasil belajar pemahaman konsep, karena kedua variable PjBL dan Self Efficacy memiliki kelebihan untuk diterapkan dalam pembelajaran berbantuan e-learning, sesuai era perkembangan ICT saat ini.

\section{Model pembelajaran flipped classroom}

Model pembelajaran flipped classroom pada masa pendemi Covid-19 di Sekolah Dasar Negeri Kecamatan Wolio di Kota Baubau yaitu kurang efektif. Hal ini dikarenakan tidak maksimalnya propes pembelajaran yang mengakibatkan tujuan pembelajaran tidak tercapai. Penyebabnya ada beberapa hal, mulai dari fungsi guru yang tidak maksimal, orang tua yang tidak bisa memberikan pemahaman dengan baik dikarenakan pekerjaan mereka serta peserta didik yang masih membutuhkan pengawasan dalam menggunakan teknologi. Terutama pada peserta didik, karena mereka menggunakan teknologi berupa gadget jadi jika tidak diawasi mereka bisa saja hanya bermain dengan gadget dan tidak mempelajari pelajaran yang diberikan oleh guru mereka (Gawise et al., 2021). Hasil penelitian menunjukkan bahwa prestasi dan kinerja peserta yang mempelajari materi kuliah melalui kuliah flipped classroom (FC) dengan menggunakan advance organizer lebih baik daripada kinerja dan prestasi rekan-rekan mereka di kelompok kontrol yang tidak disediakan oleh advance organizer. Mengingat hasil ini, penelitian ini menyimpulkan bahwa advance organizer, jika digunakan dalam flipped classroom (FC) dapat memiliki manfaat yang menarik untuk penelitian dan pengembangan keterampilan proses sains terpadu peserta didik (Elfeky et al., 2020).

Perhatikan hasil penelitian berikut, dimana flipped classroom yang telah di analisis menghasilkan tujuh temuan, sebagai berikut: (1) tren publikasi flipped classroom terus meningkat dari tahun 2013-2019; (2) sepuluh jurnal paling kontributif telah menerbitkan 88 artikel pada tahun 2019; (3) sepuluh artikel yang paling banyak dikutip telah menghasilkan 1.155 kutipan; (4) tiga urutan tertinggi kata kunci penulis yang paling banyak digunakan dalam artikel flipped classroom adalah flipped classroom, active learning, dan blended learning; (5) kolaborasi penulis dengan tautan kuat hanya terjadi pada 21 penulis melalui satu dokumen; (6) kerjasama kelembagaan dengan hubungan kuat yang terbentuk melalui 28 lembaga yang berkolaborasi; dan (7) statistik negara dibentuk menjadi tiga cluster dan tersebar di berbagai negara melalui kontribusi dari penulis yang membawahi 456 institusi. Model flipped classroom dapat disimpulkan sebagai model pendidikan yang sedang populer di kalangan peneliti saat ini (Julia et al., 2020).

\section{Model Literasi Digital}

Pembelajaran digital dengan model literasi digital peserta didik mampu meningkatkan wawasan dan hasil belajarnya, didukung dengan pembelajaran self directed learning adalah belajar mandiri untuk meningkatkan tanggung jawab peserta didik dalam proses pembelajaran. Literasi digital adalah pengetahuan dan kecakapan untuk menggunakan media digital, alat-alat komunikasi, atau jaringan dalam menemukan, mengevaluasi, menggunakan, membuat informasi, dan memanfaatkannya secara sehat, bijak, cerdas, cermat, tepat, dan patuh hukum dalam rangka membina komunikasi dan interaksi dalam kehidupan sehari-hari (Hanik, 2020). pentingnya program literasi digital yang memberikan dampak positif bagi pengetahuan, pemahaman dan keterampilan dalam menggunakan media terutama media sosial yang saat ini sering dijadikan sumber informasi oleh khalayak terutama oleh kalangan yang berusia muda. Program ini memberikan kontribusi yang signifikan pada penyebaran informasi dalam menggunakan media massa terutama media sosial yang digunakan oleh kalangan usia muda sehingga ada kesadaran dalam menggunakan media. Pada pendidikan pelatihan (diklat) ini peserta belum semua mempunyai keahlian ini dikarenakan keahlian ini memerlukan latihan yang terus menerus dan konsisten sehingga mereka dapat melakukannya dengan baik. Oleh karena itu pendidikan literasi digital merupakan solusi yang dapat dilakukan oleh pemerintah dan elemen masyarakat dan civitas akademika yang peduli terhadap kemajuan bangsa (Silvana \& Darmawan, 2018). 
Aspek kemampuan dasar literasi digital, dalam sebuah penelitian ditemukan bahwa seluruh responden mampu terhubung ke platform untuk mengikuti pembelajaran daring, dan mampu menggunakan teknologi worksheet untuk menuliskan artikel tugas sesuai format yang ditentukan. Pada aspek kedua, latar belakang pengetahuan informasi, hampir seluruh responden mampu mencari suplemen pembelajaran dalam bentuk artikel referensi dan menemukan relevansinya berdasarkan abstrak dari artikel tersebut. Pada aspek ketiga, kompetensi utama literasi digital, sebagian besar responden mampu mengutip bagian yang relevan untuk menyusun artikel tugas,serta mampu membandingkan isi dari beberapa artikel referensi. Pada aspek sikap dan perspektif pengguna informasi hamper seluruh responden mampu menuliskan sitasi dan menyusun daftar pustaka untuk artikel referensi (Irhandayaningsih, 2020).

\section{KESIMPULAN}

Model pembelajaran itu membantu peserta didik mempelajari bagaimana untuk belajar dengan gayanya sendiri, setiap model yang terpilih dan digunakan dalam aktivitas pembelajaran membantu peserta didik menyusun strategi belajarnya dan memberikan cara melakukab aktivitas belajarnya. Model pembelajaran merupakan kerangka konseptual yang menggambarkan prosedur yang sistematis dalam menyelenggarakan pembelajaran pengalaman untuk mencapai tujuan pembelajaran tertentu dan menjadi pedoman bagi guru dalam merencanakan dan melaksanakan kegiatan pembelajaran. Pembelajaran online atau daring pada masa pandemi COVID-19 sangat berpengaruh terhadap minat belajar peserta didik, peserta didik merasa bosan karena tidak bertemu dengan teman dan gurunya secara langsung. Pandemi COVID-19 yang telah mempengaruhi banyak hal termasuk kehidupan pendidikan, orang tua peserta didik, peserta didik dan proses pembelajaran, sehingga perlunya seorang guru yang memiliki tanggung jawab untuk benar-benar mendidik para peserta didik dimana para guru harus menemukan cara yang sesuai untuk mempromosikan proses pembelajaran dengan model pembelajaran yang ditemukan dalam penelitian ini adalah model pembelajaran Cooperative Learning, Model pembelajaran Problem Based Learning (PBL), model pembelajaran Project Based Learning (PjBL), Model pembelajaran flipped classroom (FC), Model pembelajaran Lietarasi Digital (LD).

\section{DAFTAR PUSTAKA}

Abazi-Bexheti, L., Kadriu, A., Apostolova-Trpkovska, M., Jajaga, E., \& Abazi-Alili, H. (2018). LMS Solution: Evidence of Google Classroom Usage in Higher Education. Business Systems Research, 9(1), 31-43. https:/ / doi.org/10.2478/bsrj-2018-0003

Adawiyah, R. (2017). Pengaruh model pembelajaran terhadap keterampilan sosial dan hasil belajar ekonomi. Research and Development Journal Of Education, 7(1), 158-171.

Agustin, M., Puspita, R. D., Nurinten, D., \& Nafiqoh, H. (2020). Tipikal Kendala Guru PAUD dalam Mengajar pada Masa Pandemi Covid 19 dan Implikasinya. Jurnal Obsesi : Jurnal Pendidikan Anak Usia Dini, 5(1), 334. https:/ / doi.org/10.31004/obsesi.v5i1.598

Artal-Sevil, J. S., Romero-Pascual, E., \& Artacho-Terrer, J. M. (2015). Blended-learning: New trends and experiences in higher education. 8th International Conference of Education.

Brahma, I. A. (2020). Penggunaan Zoom Sebagai Pembelajaran Berbasis Online Dalam Mata Kuliah Sosiologi dan Antropologi Pada Mahasiswa PPKN di STKIP Kusumanegara Jakarta. Aksara: Jurnal Ilmu Pendidikan Nonformal, 6(2), 97. https://doi.org/10.37905/aksara.6.2.97102.2020

Creswell, J. W. (2014). Research Design: Qualitative, Quantitative and Mixed Methods Approaches (Fourth Edi). SAGE Publications, Inc.

Daheri, M., Juliana, Deriwanto, \& Amda, A. D. (2020). Efektifitas WhatsApp sebagai Media Belajar Daring. Jurnal Basicedu, 4(4), 775-783. https:/ / doi.org/10.31004/ basicedu.v4i4.445

Elfeky, A. I. M., Masadeh, T. S. Y., \& Elbyaly, M. Y. H. (2020). Advance organizers in flipped classroom via e-learning management system and the promotion of integrated science process skills. Thinking Skills and Creativity, 35, 1-11. 
https:/ / doi.org/10.1016/j.tsc.2019.100622

Fauziah, P. I. N., Mansur, R., \& Mustafida, F. (2021). Efektivitas Penggunaan Aplikasi Whatsapp Dalam Pembelajaran Daring Pada Mata Pelajaran Matematika Di SDN Sumberagung 1 Kabupaten Kediri. JPMI: Jurnal Pendidikan Madrasah Ibtidaiyah, 3(2), 101-111.

Firman, F., \& Rahayu, S. (2020). Pembelajaran Online di Tengah Pandemi Covid-19. Indonesian Journal of Educational Science (IJES), 2(2), 81-89. https:/ / doi.org/10.31605/ijes.v2i2.659

Fuadi, A. S., \& Muchson, M. (2020). Penerapan Model Pembelajaran Problem Based Learning (PBL) Pada Masa Pandemi Covid 19 Dalam Meningkatkan Aktivitas Dan Hasil Belajar Siswa Pada Mata Pelajaran Produk Kreatif Dan Kewirausahaan. SENMEA Prosiding Seminar Nasional Manajemen, Ekonomi, Akuntansi Dan Call For Paper, 23-33.

Gawise, Tarno, \& Lestari, A. A. (2021). Efektifitas Pembelajaran Model Flipped Classroom masa Pandemi Covid-19 terhadap Hasil Belajar di Sekolah Dasar. Edukatif: Jurnal Ilmu Pendidikan, $3(1), 246-254$.

Hanik, E. U. (2020). Self Directed Learning Berbasis Literasi Digital Pada Masa Pandemi Covid19 Di Madrasah Ibtidaiyah. Elementary Islamic Teacher Journal, 8(1), 183-208.

Haqien, D., \& Rahman, A. A. (2020). Pemanfaatan Zoom Meeting Untuk Proses Pembelajaran Pada Masa Pandemi Covid-19. SAP (Susunan Artikel Pendidikan), 5(1), 51-56.

Herliandry, L. D., Nurhasanah, N., Suban, M. E., \& Kuswanto, H. (2020). Pembelajaran Pada Masa Pandemi Covid-19. JTP - Jurnal Teknologi Pendidikan, 22(1), 65-70. https://doi.org/10.21009/jtp.v22i1.15286

Huang, C., Wang, Y., Li, X., Ren, L., Zhao, J., Hu, Y., Zhang, L., Fan, G., Xu, J., Gu, X., Cheng, Z., Yu, T., Xia, J., Wei, Y., Wu, W., Xie, X., Yin, W., Li, H., Liu, M., ... Cao, B. (2020). Clinical features of patients infected with 2019 novel coronavirus in Wuhan, China. The Lancet, 395(10223), 497-506. https:/ / doi.org/10.1016/S0140-6736(20)30183-5

Irhandayaningsih, A. (2020). Pengukuran literasi digital pada peserta pembelajaran daring di masa pandemi Covid-19. Anuva, 4(2), 231-240.

Joyce, B., Weil, M., \& Calhoun, E. (2015). Models of Teaching (9th Editio). Pearson Education, inc. Julia, J., Dolifah, D., Afrianti, N., Isrokatun, I., Soomro, K. A., Erhamwilda, E., Supriyadi, T., \& Ningrum, D. (2020). Flipped classroom educational model (2010-2019): A bibliometric study. European Journal of Educational Research, 9(4), 1377-1392. https://doi.org/10.12973/eujer.9.4.1377

Juwanti, A. E., Salsabila, U. H., Putri, C. J., Nurany, A. L. D., \& Cholifah, F. N. (2020). ProjectBased Learning (PjBL) untuk PAI Selama Pembelajaran Daring. Jurnal Pendidikan Islam AlIlmi, 3(2), 72-82. https:/ / doi.org/10.32529/al-ilmi.v3i2.752

Kinteki, R., Setyosari, P., Sumarmi, \& Ulfa, S. (2019). The effect of flipped classroom models and Self Efficacy on students concept understanding and application of the hydrology. Ecology, Environment and Conservation Paper, 25(4), 115-121.

Kokotsaki, D., Menzies, V., \& Wiggins, A. (2016). Project-based learning: a review of the literature Improving schools. Durham Research Online Deposited, 19(3), 267-277.

Munawaraoh, I. (2005). Virtual Learning dalam Pembelajaran Jarak Jauh. Majalah Ilmiah Pembelajaran, 2(1), 171-181.

Pohan, S. S., \& Suparman. (2020). Perspektif Literasi Digital Bagi Guru Sekolah Dasar. Jurnal IlmuIlmu Sejarah, Sosial, Budaya Dan Kependidikan, 7(1), 164-178.

Pujiasih, E. (2020). Membangun Generasi emas dengan Variasi Pembelajaran Online di Masa Pandemi Covid-19. Ideguru: Jurnal Karya Ilmiah Guru, 5(1), 42-48.

Putria, H., Maula, L. H., \& Uswatun, D. A. (2020). Analisis Proses Pembelajaran Dalam Jaringan (DARING) Masa Pandemi COVID-19 pada Guru Sekolah Dasar. Jurnal Basicedu, 3(2), 861872. https:/ / doi.org/10.31004/basicedu.v4i4.460

Rakhman, A., \& Alam, S. K. (2020). Implementasi Pembelajaran Jarak Jauh dalam Meningkatkan Life Skill pada Anak Usia Dini. Jurnal Tunas Siliwangi, 6(2), 1-9.

Romadhon, M. S., Rahmah, A., \& Wirani, Y. (2019). Blended learning system using social media for college student: A case of tahsin education. Procedia Computer Science, 161, 160-167. 
https:/ / doi.org/10.1016/j.procs.2019.11.111

Safaruddin, Degeng, I. N. S., Setyosari, P., \& Murtadho, N. (2020). The effect of PJBL with WBL media and cognitive style on students' understanding and science-integrated concept application. Jurnal Pendidikan IPA Indonesia, 9(3), 384-395. https:/ / doi.org/10.15294/jpii.v9i3.24628

Salehudin, M. (2020a). Dampak Covid-19: Guru Mengadopsi Media Sosial Sebagai E-learning Pada Pembelajaran Jarak Jauh. Jurnal MUDARRISUNA, 10(1), 1-16.

Salehudin, M. (2020b). Project-Based Learning Berbantuan E-learning: Pengaruhnya Terhadap Hasil Belajar. Tadrib: Jurnal Pendidikan Agama Islam, 6(1), 28-40.

Satgas. (2020). Data Sebaran.

Setyorini, I. (2020). Pandemi covid-19 dan online learning: Apakah Berpengaruh Terhadap Proses Pembelajaran Pada Kurukulum 13? Journal of Industrial Engineering $\mathcal{E}$ Management Research (Jiemar), 01(1), 95-102.

Shao, Y., \& Wu, J. (2020). IDM editorial statement on the 2019-nCoV. Infectious Disease Modelling, 5, 233-234. https://doi.org/10.1016/j.idm.2020.01.003

Silvana, H., \& Darmawan, C. (2018). Pendidikan Literasi Digital Di Kalangan Usia Muda Di Kota Bandung. Pedagogia, 16(2), 146. https:// doi.org/10.17509/pdgia.v16i2.11327

Sugiono. (2010). Metode Penelitian Pendidikan; Pendekatan Kuantitatif, Kualitatif dan RED (cetakan ke). Alfabeta, CV.

Syarifudin, A. S. (2020). Impelementasi Pembelajaran Daring Untuk Meningkatkan Mutu Pendidikan Sebagai Dampak Diterapkannya Social Distancing. Jurnal Pendidikan Bahasa Dan Sastra Indonesia Metalingua, 5(1), 31-34. https:/ / doi.org/10.21107/ metalingua.v5i1.7072

Vhalery, R., Setyastanto, A. M., \& Alfilail, S. N. (2021). Pembelajaran Berbasis Online "Zoom" Pada Kesiapan Belajar Mahasiswa Di Masa Pandemi Covid-19. Research and Development Journal of Education, 7(1), 215. https://doi.org/10.30998/rdje.v7i1.9329

Wang, R., Zhang, X., Irwin, D. M., \& Shen, Y. (2020). Emergence of SARS-like coronavirus poses new challenge in China. Journal of Infection, 80(3), 350-371. https:/ / doi.org/10.1016/j.jinf.2020.01.017

Yatun, S., Salehudin, M., Komariah, D. L., Aminda, N. E. R., Hidayati, P., Latifah, N., Aisyah, \& Yani. (2020). Persepsi Orang Tua dan Guru dalam Menanamkan Disiplin Anak Usia Dini pada Pembelajaran Online. Jurnal Ilmiah Potensia, 6(1), 1-10.

Yunitasari, R., \& Hanifah, U. (2020). Pengaruh Pembelajaran Daring terhadap Minat Belajar Siswa pada Masa COVID-19. Edukatif: Jurnal Ilmu Pendidikan, 2(3), 232-243. 